\title{
Concrete Strength Characteristics with the Addition of Polypropylene Fiber from Strapping Band Material
}

\author{
Noviyanthy Handayani ${ }^{1}$, Norseta Ajie Saputra ${ }^{2}$ \\ Program Studi Teknik Sipil, Fakulas Teknik dan Informatika, Universitas Muhammadiyah Palangka \\ Raya Jl. RTA. Milono Km. 1,5 Palangka Raya, Kalimantan Tengah ${ }^{1,2}$ \\ vianthy84@yahoo.com ${ }^{1}$,norseta.ajie@gmail.com²
}

\begin{abstract}
Concrete mixtures can be added to improve the characteristics of concrete or reduce the composition of concrete. Materials that can be used as additives in concrete mixes are polypropylene fibers from strapping band materials. The research carried out is a technical examination of the ingredient concrete and determine the design of the concrete mix composition. Mixing is done in 2 (two) stages, normal concrete mixing and concrete mixing with additional strapping band material. The addition of strapping band fibers is done with 3 (three) variations namely $0.5 \%, 0.75 \%$ and $1 \%$ of the weight of cement. The results showed that more and more strapping band fibers would reduce the compressive strength of concrete. The compressive strength value of normal concrete is $302.55 \mathrm{~kg} / \mathrm{cm}^{2}$. While the compression strength value of concrete with the addition of strapping band fibers of $0.5 \%, 0.75 \%$ and $1 \%$ obtained respectively $271.34 \mathrm{~kg} / \mathrm{cm}^{2}, 262.11 \mathrm{~kg} / \mathrm{cm}^{2}$ and $234.14 \mathrm{~kg} / \mathrm{cm}^{2}$.
\end{abstract}

Keywords: Normal Concrete, Fiber Strapping Band, Concrete Compression Strength

\section{Introduction}

Concrete is the result of engineering materials that are related to building construction. In its development, concrete as a solid type of building construction due to types and material. Concrete construction is expected to be able to face conditions in which concrete is planned without experiencing damage during the planned period [1]. The relationship between the ability of concrete to withstand loads and the constituent structures can be important because several constituent materials can have a significant effect on the characteristics of the concrete itself. The characteristic in question is the quality of the concrete achieved by the concrete constituent mixture. In general, the basic ingredients of concrete are fine aggregate, coarse aggregate, cement, and water. However, in its development, the building blocks of concrete can be mixed with added ingredients or other additives.

The addition of materials to concrete usually aims to improve the characteristics of the concrete and the durability of concrete against certain fast conditions. Some added materials that can increase the compressive strength of concrete include palm fibers [2], PET plastic waste [3], broken glass [4], and waste strapping bands [5], [6], [7]. Prasetyo's research [5] the 
ratio of the strapping band fiber size increases the split tensile strength value of the SCC control concrete. Research [6] used a variation of fiber strapping bands $0 \%, 1,25 \%, 2,5 \%$, $3,75 \%$, and $5 \%$ increase in maximum compressive strength occurred at the addition of $5 \%$ fiber of $29,67 \%(40.3 \mathrm{MPa})$ and the split tensile strength of $60,94 \%(1,03 \mathrm{MPa})$. Whereas in research [7], the use of strapping bands on lightweight concrete with variations of FS- $0 \%$, FS$3 \%$, FS- $6 \%$ FS- $9 \%$ obtained the best results at 28 days of age when adding fiber strapping bands to FS- $9 \%$, the maximum compressive strength is $8,58 \mathrm{~N} / \mathrm{mm}^{2}$, the maximum tensile strength is $0,45 \mathrm{~N} / \mathrm{mm}^{2}$ and the weight volume is $1140 \mathrm{~kg} / \mathrm{m}^{3}$. Based on these conditions, the addition of Polypropylene fiber material from the Strapping-Band material was tested in the K.250 quality concrete mixture. It is hoped that this addition can obtain concrete characteristics that are different from normal concrete conditions with the original mixture.

\section{Literature Review}

\subsection{Qualification of concrete}

Based on the classification by the Ministry of Public Works, the quality of concrete based on its compressive strength is divided into three types, namely low strength concrete, medium quality concrete and high quality concrete [8]. The classification division based on the compressive strength of the concrete is stated in Table 1 below:

Table 1. Type of concrete

\begin{tabular}{|c|c|c|c|}
\hline $\begin{array}{l}\text { Type of } \\
\text { concrete }\end{array}$ & $\begin{array}{l}\text { Compression } \\
\text { strength /f"c } \\
\text { (MPa) } \\
\end{array}$ & $\begin{array}{c}\sigma b k^{\prime} \\
(\mathrm{kg} / \mathrm{cm} 2)\end{array}$ & Description \\
\hline $\begin{array}{l}\text { High strength } \\
\text { concrete }\end{array}$ & $35-65$ & K400 - K800 & $\begin{array}{l}\text { Generally for prestressed concrete such } \\
\text { as prestressed concrete piles, prestressed } \\
\text { concrete girders, prestressed concrete } \\
\text { plates, and etc. }\end{array}$ \\
\hline $\begin{array}{l}\text { Normal } \\
\text { concrete }\end{array}$ & $20-<35$ & $\mathrm{~K} 250-<\mathrm{K} 400$ & $\begin{array}{l}\text { Generally used for reinforced concrete } \\
\text { such as bridge floor slabs, reinforced } \\
\text { concrete girders, diaphragms, precast } \\
\text { concrete curbs, reinforced concrete } \\
\text { culverts, bridge substructures. }\end{array}$ \\
\hline \multirow[t]{2}{*}{$\begin{array}{l}\text { Low strength } \\
\text { concrete }\end{array}$} & $15-<20$ & $\mathrm{~K} 175-<\mathrm{K} 250$ & $\begin{array}{l}\text { Generally used for unreinforced concrete } \\
\text { structures such as cyclops, sidewalks, and } \\
\text { empty masonry filled with mortar, } \\
\text { masonry. }\end{array}$ \\
\hline & $10-<15$ & K125 - < K175 & $\begin{array}{l}\text { Used as a base floor, backfilling with } \\
\text { concrete. }\end{array}$ \\
\hline
\end{tabular}

Source : Puslitbang Prasarana Transportasi, Divisi 7 - 2005

\subsection{Fiber Concrete}

Fiber concrete (Polypropelyne concrete) is concrete construction with materials consisting of cement, fine aggregate, coarse aggregate, and a small amount of fiber (Polypropelyne) randomly scattered in fresh concrete [9]. Fiber concrete can also be interpreted as a composite material consisting of ordinary concrete and other materials in the form of fibers. The fibers 
used are generally with a diameter of 5 to $500 \mu \mathrm{m}$ (micrometer) and a length of about 25-100 $\mathrm{mm}$. Fiber materials can be asbestos, plant fibers (straw, bamboo, palm fiber), plastic fibers, glass fibers, or steel fibers. Fiber concrete is usually divided into 3 (three) categories, including:

a) Low-fiber concrete with a fiber content of less than 1 percent by volume of concrete

b) Medium-fiber concrete with a fiber content of 1 to 5 percent by volume of concrete

c) High-fiber concrete with fiber content reaching 5 to 15 percent of the volume of concrete.

Based on these conditions, it can be seen that many fiber materials can be used to improve or enhance the mechanical properties of concrete. The mechanical properties of concrete include increasing the ductility and flexural strength of the concrete. In this case, it is reducing the occurrence of fine cracks and larger cracks to avoid structural collapse [10].

\subsection{Mix design concrete}

Concrete mix design uses the SNI 03-2834-1993 method [1] with the compressive strength of the K-250 plan at the treatment age of 7 days, 14 days, and 21 days. The concrete specimen is cubic with dimensions of $15 \mathrm{~cm} \times 15 \mathrm{~cm} \times 15 \mathrm{~cm}$ for the compressive strength test.

\subsection{Compression strength test}

Testing the compressive strength of concrete, the test object is a concrete cube with dimensions of $15 \mathrm{~cm} \times 15 \mathrm{~cm}$ and a height of $15 \mathrm{~cm}$. The specimen is pressed with load $\mathrm{P}$ until it collapses. Because there is a compressive load $\mathrm{P}$, there is a compressive stress of concrete $(\sigma c)$ equal to the load $(\mathrm{P})$ divided by the cross-sectional area of the concrete $(\mathrm{A})$, so that it is formulated as follows:

$$
\sigma_{c}=\frac{P}{A}
$$

$$
\begin{array}{ll}
\sigma_{\mathrm{c}} & =\text { compressive stress of concrete, } \mathrm{MPa} \\
\mathrm{P} & =\text { load, Newton } \\
\mathrm{A} & =\text { cross-sectional area, } \mathrm{mm}^{2}
\end{array}
$$

\section{Method of research}

\subsection{Research Flowchart}

The research was carried out in stages so that the research results obtained were very accurate, and the process of the research implementation flow was as shown in Figure 1 below. 


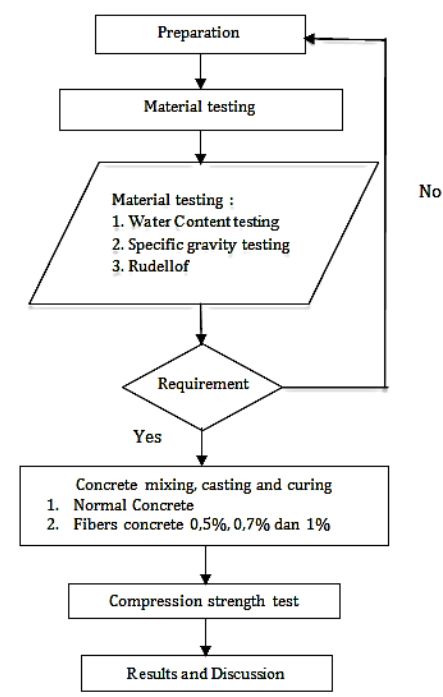

Fig. 1. Research Flowchart

\subsection{Examination of Aggregate Material Characteristics}

The material used is coarse aggregate is crushed rock originating from Ex. Merak, while the fine aggregate is natural sand from Tangkiling village Km 29 Palangka Raya city. Material testing carried out is: Water Content testing, Specific gravity testing, and Resistance Test. The test implementation follows the procedure for making a normal concrete mix plan [11].

\subsection{Concrete Mixing, Casting and Curing}

The concrete used in the test is normal concrete with a compressive strength of K.250 quality plan. The test object is a concrete cube with dimensions of $15 \mathrm{~cm} \times 15 \mathrm{~cm} \times 15 \mathrm{~cm}$. As for the addition of the strapping band fibers, the percentage variations were varied from $0.5 \%, 0.7 \%$, and $1 \%$ to the weight of cement. The details of the number of concrete specimens are as follows on table 2 below:

Table 2. The numbers of concrete sampel

\begin{tabular}{clcc}
\hline No. & \multicolumn{1}{c}{ Variation of concrete } & The age of the concrete & Number of samples \\
\hline 1. & Normal concrete & 7 & 3 \\
& & 14 & 3 \\
2. & Normal concrete K- $250+0,5 \%$ & 21 & 3 \\
& Strapping band fibers & 7 & 3 \\
& & 14 & 3 \\
3. & Normal concrete K-250 +0,7\% & 21 & 3 \\
& Strapping band fibers & 7 & 3 \\
& & 14 & 3 \\
4. & Normal concrete K-250 +1,0\% & 7 & 3 \\
& Strapping band fibers & 14 & 3 \\
& & 21 & 3 \\
\hline & Total & 36 \\
\hline
\end{tabular}




\subsection{Data processing}

Data processing is done by recording the results of measurements of the characteristics of the concrete materials and the results of the concrete compression strength for each variation. The test is carried out at the planned concrete age starting from 7 days, 14 days, and 21 days, although the perfect concrete condition is at the age of 28 days. To obtain these results, a concrete conversion table [12] is used as below.

Table 3. Comparison of Concrete Compressive Strength at Various Ages

\begin{tabular}{lccccccc}
\hline The age of concrete & $\mathbf{3}$ & $\mathbf{7}$ & $\mathbf{1 4}$ & $\mathbf{2 1}$ & $\mathbf{2 8}$ & $\mathbf{9 0}$ & $\mathbf{3 6 5}$ \\
\hline Ordinary Portland cement & 0,40 & 0,65 & 0,88 & 0,95 & 1,00 & 1,20 & 1,35 \\
$\begin{array}{l}\text { Portland cement with high } \\
\text { initial strength }\end{array}$ & 0,55 & 0,75 & 0,90 & 0,95 & 1,00 & 1,15 & 1,20 \\
\hline
\end{tabular}

Source: Peraturan Beton Bertulang Indonesia, 1971

\section{Results and Discussion}

\subsection{Results of Material Characteristics Testing}

The research was conducted at the Structural Laboratory of the Faculty of Engineering and Informatics UM Palangkaraya, obtained the characteristics of the fine aggregate material and the coarse aggregate of the concrete mixture. These results can be seen in tables 4 and 5 below.

Table 4. The Characteristics of fine aggregate

\begin{tabular}{lccc}
\hline \multicolumn{1}{c}{ Testing } & unit & result & requirements \\
\hline Water content & $\%$ & 2,21 & - \\
Specific weight (SSD) & $\mathrm{gr} / \mathrm{cm}^{3}$ & 2,574 & $1,20-2,80$ \\
Absorption & $\%$ & 1,585 & - \\
Passed through No. 200 sieve & $\%$ & 7,84 & - \\
Mud content & $\%$ & 2,80 & $<5 \%$ \\
Sand gradation zone & - & zone III & - \\
Modulus of fineness & $\%$ & 2,643 & (SK SNI 03-2834-1993) \\
& & &
\end{tabular}

Source : the result of testing (2019)

Table 5. The Characteristics of coarse aggregate

\begin{tabular}{lccc}
\hline \multicolumn{1}{c}{ Testing } & unit & result & requirements \\
\hline Water content & $\%$ & 1,88 & - \\
Specific weight (SSD) & $\mathrm{gr} / \mathrm{cm}^{3}$ & 2,556 & $1,20-2,80$ \\
Absorption & $\%$ & 2,190 & - \\
Sludge levels & $\%$ & 1,79 & $<5 \%$ \\
Coarse gradation zone & $\mathrm{mm}$ & 40 & - \\
Rudellof & $\%$ & 26,31 & (SK SNI 03-2834-1993) \\
Modulus of fineness & $\%$ & 3.164 & $1,5-30 \%$ \\
& & & (SK SNI 03-2834-1993) \\
\hline
\end{tabular}

Source : the result of testing (2019) 


\subsection{Concrete Test Results}

Based on the results of testing the property materials of concrete that have met the requirements of the specifications, the mixing is carried out based on the Standard Procedures for Normal Concrete Making [11]. The results of the table below are obtained.

Table 6. Result of fibers concrete K.250

\begin{tabular}{|c|c|c|c|}
\hline Concrete spesimens & $\begin{array}{c}\text { Ages of concrete } \\
\text { (hari) }\end{array}$ & $\begin{array}{c}\text { Compression strength } \\
\text { average }\left(\mathrm{kg} / \mathrm{cm}^{2}\right)\end{array}$ & $\begin{array}{l}\text { Conversion Compression } \\
\text { strength } 28 \text { days }\left(\mathrm{kg} / \mathrm{cm}^{2}\right)\end{array}$ \\
\hline \multirow{3}{*}{ Normal Concrete } & 7 & 208,89 & 321,37 \\
\hline & 14 & 259,26 & 294,61 \\
\hline & 21 & 280,00 & 291,67 \\
\hline Normal concrete K- & 7 & 194,07 & 298,58 \\
\hline $250+0,5 \%$ Strapping & 14 & 228,15 & 259,26 \\
\hline band fibers & 21 & 245,93 & 256,17 \\
\hline Normal concrete K- & 7 & 174,82 & 268,95 \\
\hline $250+0,7 \%$ Strapping & 14 & 232,59 & 264,31 \\
\hline band fibers & 21 & 242,96 & 253,09 \\
\hline Normal concrete K- & 7 & 167,41 & 257,55 \\
\hline $250+1,0 \%$ Strapping & 14 & 200,00 & 227,27 \\
\hline band fibers & 21 & 208,89 & 217,59 \\
\hline
\end{tabular}

Source : the result of testing (2019)

\subsection{Compression strength testing}

Based on the results of the tests, it obtained a comparison of the value of the compressive strength of concrete in normal concrete conditions and the addition of varied strapping band fibers concrete. The test results figured in the image below:

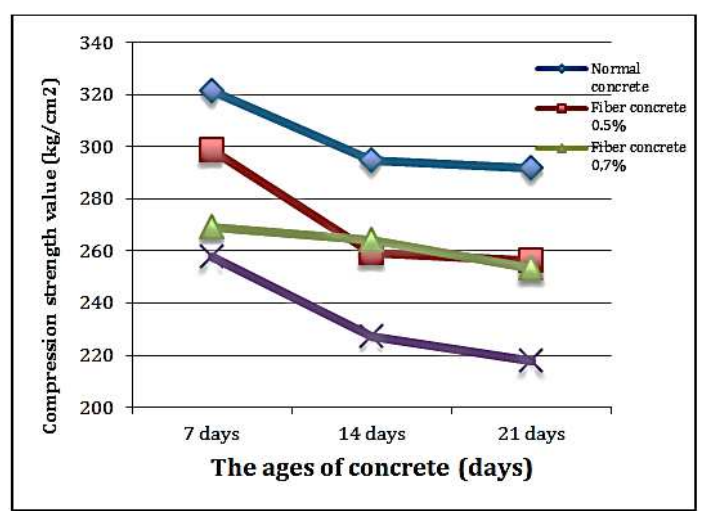

Fig. 2. Comparison of compression strength values

Based on the results in Figure 2, it shows an increase in the average compressive strength value of each concrete mixture condition along with the increasing age of the concrete. But with the addition of Strapping Band fibers, the compressive strength of the concrete that occurs is getting lower. It showed where the graph of normal concrete increase is at the top and bottom, respectively, followed by the graphic of increasing concrete with the addition of $0.5 \%, 0.7 \%$, and $1.0 \%$ fiber. From the graph above, show that the average reduction in the 
value of concrete strength with the addition of Strapping Band fibers has different percentages. The percentage reduction in the variations of $0.5 \%$ Strapping Band fibers ranges from $7 \%$ to $12 \%$. The decrease in the compressive strength value at the addition of $0.7 \%$ of the Strapping Band fibers ranges from $13 \%$ to $16 \%$. And with the addition of $1 \%$ of the Strapping Band fiber, the compressive strength value is reduced by $19 \%$ to $25 \%$.

Then, the conversion of concrete strength values is carried out based on table 3 at the age of the concrete plan 28 days. The results comparison showed the following figure.

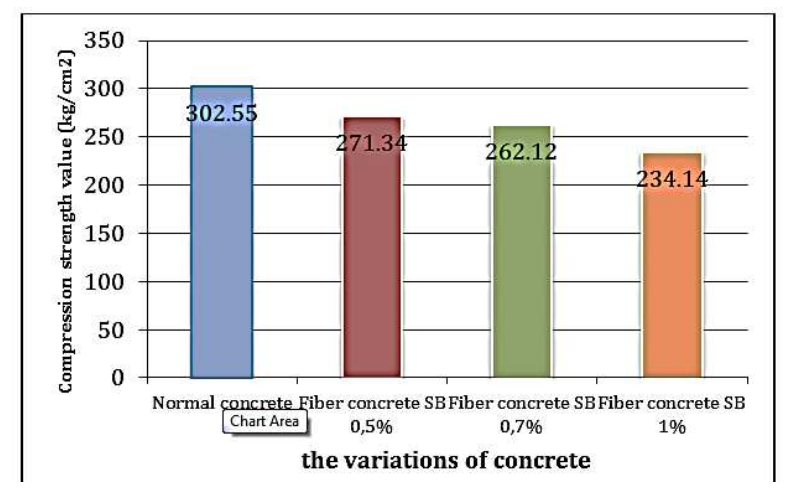

Fig. 3. Compression strength values for 28 days ages of concrete

In Figure 3, we can see the comparison of the compressive strength values after converting the concrete design age for 28 days. From the curve, its obtained that the compressive strength of normal concrete reaches $302.55 \mathrm{~kg} / \mathrm{cm}^{2}$. As the test results stated earlier was found that the compressive strength of the concrete decreased in the addition of the strapping band fibers to the normal concrete compressive strength. Sequentially, the compressive strength values of concrete with the addition of strapping band fibers from $0.5 \%, 0.7 \%$ and $1 \%$ were 271.34 $\mathrm{kg} / \mathrm{cm}^{2}, 262.11 \mathrm{~kg} / \mathrm{cm}^{2}$ and $234.14 \mathrm{~kg} / \mathrm{cm}^{2}$. Sequentially decreasing the compressive strength of the concrete addition strapping band fibers to the compressive strength of normal concrete. The conversion of the 28 days plan age ranged from $10,31 \%$ to $22,61 \%$. From the test results, the addition of a strapping band can reduce the value of the compressive strength of concrete. Its because the original material used is plastic. The results of this study are inverse to research [5], [6], [7] that showed an increase in the compressive strength value of concrete on the use of fiber between $0 \%-1 \%, 5 \%$ and $9 \%$.

However, overall the results of the concrete compressive strength test by meeting the addition of the strapping band fibers have satisfied the design requirements of $250 \mathrm{~kg} / \mathrm{cm} 2$. So we can say that the addition of strapping band fibers to the concrete still meets the requirements quality of K-250 concrete.

\section{Conclusion and suggestions}

\subsection{Conclusion}

The conclusions from the research that is as follows: 
a) Normal concrete compressive strength at 21 days of concrete reaches a maximum value of $280,00 \mathrm{~kg} / \mathrm{cm}^{2}$. After converting the compressive strength of concrete at the design age of 28 days it reaches $302,55 \mathrm{~kg} / \mathrm{cm}^{2}$.

b) The compressive strength value of concrete with the addition of Strapping Band fibers in the 7 days, 14 days, and 21 days decreased to normal concrete. The percentage reduction due to $0.5 \%$ Strapping band fibers ranged from $7 \%-12 \%$. For $0.7 \%$ of the Strapping band fibers ranged from $13 \%-16 \%$. And with the addition of $1 \%$ of Strapping Band fibers, the compressive strength of the concrete is reduced by $19 \%-25 \%$.

c) For normal concrete compressive strength values, the conversion plan age of 28 days reaches $302,55 \mathrm{~kg} / \mathrm{cm}^{2}$. Respectively, the compressive strength values of concrete with the addition of strapping band fibers of $0.5 \%, 0.7 \%$ and $1 \%$ are $271.34 \mathrm{~kg} / \mathrm{cm}^{2}, 262.11$ $\mathrm{kg} / \mathrm{cm}^{2}$ and $234.14 \mathrm{~kg} / \mathrm{cm}^{2}$.

d) At the conversion of 28 days of concrete, the decrease in the compression strength value of the concrete due to the addition of the strapping band fibers ranged from $10.31 \%$ $22.61 \%$.

e) From the overall test results, we can say that the addition of strapping band fibers can reduce the compressive strength of concrete. However, the compressive strength value of the concrete obtained has met the design requirements of the K-250 quality concrete plans with a concrete compressive strength greater than $250 \mathrm{~kg} / \mathrm{cm}^{2}$.

\subsection{Suggestions}

Suggestions that can give from the results of the research that have done are as follows:

a. It is necessary to carry out further testing on the types of fibers from other materials besides the straps to increase the compressive strength of the concrete.

b. Besides, it is necessary to use aggregate variations based on the size of the existing grains with the same fiber type or to keep using fibers from the strapping band.

c. For further research, a concrete tensile strength test can be carried out from the existing test results to see other parameters of the concrete with the addition of the strapping band.

\section{Acknowledgements}

This research can be carried out because of the assistance of the Civil Engineering Study Program, Muhammadiyah University of Palangkaraya.

\section{References}

[1] Kurniawandy, A., Darmayanti, L., \& Pulungan, U. H. (2012). Pengaruh Intrusi Air Laut, Air Gambut, Air Kelapa, Dan Air Biasa Terhadap Kuat Tekan Beton Normal. Jurnal Sains dan Teknologi, 11(2). https://jst.ejournal.unri.ac.id/index.php/JST/article/view/3337

[2] Winarto, S. (2018). Pemanfaatan Serat Ijuk Sebagai Material Campuran Dalam Beton Untuk Meningkatkan Kemampuan Beton Menahan Beban Tekan Studi Kasus: Pembangunan Homestay Singonegaran Kediri. UKaRsT, 1(1), 1-10.

DOI : $10.30737 / \mathrm{u}$ karst.v1i1.79 
[3] Armidion, Rocky, and Tanjung Rahayu. Peningkatan Nilai Kuat Tarik Belah Beton Dengan Campuran Limbah Botol Plastik Polyetylene Terephthalate (PET). Konstruksia 10.1 (2019): 117-126.

https://jurnal.umj.ac.id/index.php/konstruksia/article/viewFile/3877/2877

[4] Ikhsan, M. N., Prayuda, H., \& Saleh, F. (2017). Pengaruh Penambahan Pecahan Kaca Sebagai Bahan Pengganti Agregat Halus dan Penambahan Fiber Optik Terhadap Kuat Tekan Beton Serat. Semesta Teknika, 19(2), 148-156.

https://host-pustaka.umy.ac.id/index.php/st/article/view/2037

[5] Prasetyo, W. H. (2018). Pengaruh rasio ukuran serat Polypropylene (PP)" strapping band" pada Self Compacting Concrete (SCC) terhadap sifat mekanis beton (Doctoral dissertation, Universitas Negeri Malang). http://repository.um.ac.id/id/eprint/45424

[6] Zuraidah, S., Sujatmiko, B., Hastono, K. B., Tiro, H., \& Hartono, T. (2019, December). Utilization of Strapping Band Waste for Reviewed Mortar Againsts Compressive and Split Tensile Strength. In Journal of Physics: Conference Series (Vol. 1364, No. 1, p. 012019). IOP Publishing. https://iopscience.iop.org/article/10.1088/17426596/1364/1/012019/pdf

[7] Zuraidah, S., Hastono, B., \& Lidia, M. A. (2018, October). Penggunaan Serat Polyprophylene Dari Limbah Strapping Band Terhadap Kuat Tekan Dan Kuat Tarik Belah Beton Ringan. In Seminar Nasional Ilmu Terapan Penguasaan Teknologi dan Bahasa Asing Dalam Menghadapi Pertumbuhan Ekonomi Dunia di Era Revolusi Industri 4.0 (pp. 1-8). Universitas Widya Kartika. http://repository.unitomo.ac.id/id/eprint/1339

[8] Departemen Pekerjaan Umum, Puslitbang Prasarana Transportasi, Spesifikasi Umum 2010 (Revisi 3) Divisi 7 Struktur Seksi 7.1 Beton,

[9] ACI International Conference, (1997) High Performance Concrete and Design Material and Recend Advance is Concrete

[10] Suhendro, B. (1991). Pengaruh Pemakaian Fiber Secara Parsial pada Perilaku dan Kapasitas Balok Beton Bertulang. In Seminar Mekanika Bahan Untuk Meningkatkan Potensi Bahan Lokal, PAU Universitas Gadjah Mada, Yogyakarta.

[11] SK SNI 03-2834-1993 Tata Cara Pembuatan Rencana Campuran Beton Normal, Departemen Pekerjaan Umum, Pusjatan - Balitbang, Jakarta

[12] Direktorat Jenderal Cipta Karya (1971) Peraturan Beton Bertulang Indonesia N.I.-2 Deparetemen Pekerjaan Umum dan Tenaga Listrik, Jakarta 